\title{
Dissolution of the Unified Progressive Party Case in Korea: A Critical Review with Reference to the European Court of Human Rights Case Law
}

\author{
Jongcheol Kim*
}

This article aims to introduce and critically analyze the jurisprudence and its application in the UPP case in South Korea with reference to the ECtHR case law. In this controversial case, the CCK decided to dissolve the UPP and, without any basis in positive law, disqualify five National Assembly members affiliated with it. It is argued that when the CCK attempted to articulate the principle of proportionality that the ECtHR case law has firmly developed in this field and to apply it to this case, standards governing the dissolution of political parties were distorted at least in two ways. First, it substituted 'social need' for "pressing social need." Second, it deliberately omitted the requirement of 'sufficient imminence.' In addition, the reasoning of the majority of eight justices based upon the rule of evidence in civil proceedings can also be criticized for being too abrupt to be justified in this highly controversial case of constitutional importance.

* Professor at Yonsei University School of Law, Seoul, Korea. LL.B./LL.M. (Seoul Nat'l Univ.), Ph.D. in Law (LSE). ORCID: http://orcid.org/0000-0001-9731-5751. This article is a fully revised and updated version of the paper presented at the International Conference held at the University of Hong Kong Centre for Comparative and Public Law under the title of "Democratization and Constitutional Adjudication in Hong Kong and South Korea: Comparative Perspectives" on February 12, 2015. Some of main arguments raised in this paper were published in a peper written in Korean under the title of Is the Constitutional Court the Sovereign Institution? - Dissolution of the Unified Progressive Party and Constitutional Identity of the Republic of Korea [헌법재판소는 주권적 수임기관인가?: 대한민국의 헌법적 정체성과 통합진보당 해산결정]<available only in Korean> 151 JusticE 29-71(2015). This research was supported by the Ministry of Education and the National Research Foundation of Korea (NRF-2015S1A3A2046920). The author may be contacted at: jkim386@yonsei.ac.kr / Address: Yonsei University School of Law, 50 Yonseiro, Seodaemungu, Seoul 03722 Korea.

DOI: http://dx.doi.org/10.14330/jeail.2017.10.1.07 


\section{Keywords}

Dissolution of Political Party, United Progressive Party, Constitutional Court of Korea, ECtHR, Democratic Basic Order

\section{Introduction}

On December 19, 2014, the Constitutional Court of Korea ("CCK") decided to dissolve the Unified Progressive Party ("UPP”) and to disqualify the five National Assembly members affiliated with the UPP. It is the first case of this kind in Korean constitutional history after 1948.

The dissolution process was based upon Articles 8(4), 111(1), and 113(1) of the Constitution of the Republic of Korea ("ROK"), while the disqualification decision was made without any basis in written law. Article 8(4) endows the Executive with the power to bring before CCK an action that can dissolute a political party, which has the purposes or activities of violating the so-called "democratic basic order" (民主 的 基本秩序). Also, Articles 111(1) and 113(1) presents that CCK may make a decision to dissolve a political party with the concurrence of at least six out of nine justices. The major legal issues at stake, in this case, are basically two-fold: first, what are the requirements for the dissolution of a political party? i.e., whether or not the party violated or abused the democratic basic order?; second, how strict a standard might be applied to discover such an infringement? These two issues should be tackled best through considering the fundamental principles of why democracy pertaining to value relativism and plurality of political powers institutionalizes the mechanism of compulsory exclusion of a political party from the official political system.

The historical and constitutional ramification of the UPP case allow us to assess the present circumstances of Korean democracy and the role of constitutional adjudication in the democratic order in Korea.

The rudimentary objective of this research is to introduce the essential elements of CCK's jurisprudence in this case and to dissect them critically with distinct references to the case law of the European Court of Human Rights ("ECtHR"). This paper is made out of five parts including a short Introduction and Conclusion. Part two will discuss the idea and ideology of modern constitutional democracy. Part three will break down the jurisprudence of CCK in the UPP dissolution case. Part four will criticize the reasoning of CCK in this case. 


\section{Idea and Ideology of Modern Constitutional Democracy}

In the first stage of modern constitutional democracy, judicial dissolution of political parties was regarded as being incompatible with the value relativism cherished by free democracy. It was the Basic Law (Grundgesetz) of West Germany in the wake of the Second World War that challenged this idea and constitutionalized this stern measure for the sake of the purported 'militant democracy' or 'defending democracy' (Streitbare Demokratie). ${ }^{1}$ Numerous new democracies including Korea took after the West German model of militant democracy on the ground that such adversaries of democracy as the followers of Nazism could not be allowed to enjoy the political freedom to demolish the democratic order itself. However, this mechanism carries a reasonable peril of misuse or abuse by authoritarian regimes to oppress their political oppositions. Hence, the dissolution of political parties is a "double-edged sword" for democracy. From one viewpoint, it is a "self-defending measure" to safeguard democracy itself, while, on the other, it could be an 'unlawful alibi' of political tyranny.

The ambivalent nature of political party dissolution affects the foundations of democracy such as elections and the general functioning of government. Being well-recognized by the Council of Europe where some member States, particularly those governed until recently by authoritarian regimes, introduced it. The European Commission for Democracy through Law (hereinafter Venice Commission), an advisory arm of the Council of Europe, undertook a research on the prohibition of political parties and analogous measures by adopting the guidelines in this field in 1999, which was published in 2000. The core ideas of these guidelines were reaffirmed as 'good practices' issued by the Venice Commission in 2009.

While the Venice Commission has contributed to the development of political practices as opposed to the judicial norms regarding the dissolution of political parties, the ECtHR has played a significant role in formulating judicial norms in this area. In 1998, the ECtHR declared the Turkish Constitutional Court's decision to dissolve the United Communist Party of Turkey for violating Article 11 of the European Convention for the Protection of Human Rights ("ECHR"). Since then, the

1 For details on 'militant democracy,' see C. Lowenstein, Militant Democracy and Fundamental Rights I, 31 Ам. Pol. Scr. Rev. 417 (1937); S. Avineri, Introduction, in Militant Democracy 1 (A. Sázo ed., 2004).

2 These practices invited by the Parliamentary Assembly of the Council of Europe in 2007 do not have a legal binding force, but are a 'yardstick' for public authorities and jurisdictional bodies to assess the practice of political parties. See European Commission for Democracy through Law (Venice Commission), CDL-AD (2009) 021, at 5, ๆ 5, available at http://www.venice.coe.int/webforms/documents/?pdf=CDL-AD(2009)021-e (last visited on Apr. 22, 2017). 
Court has dealt with a number of cases on the dissolution of political parties.

\section{The Jurisprudence of the CCK in the UPP Case}

\section{A. The Facts}

The UPP was founded by the joint efforts of the former progressive parties - the Democratic Labor Party, the Participation Party, and the New Unified Solidarity for the Progressives - on December 5, 2011. In the general election on April 11, 2012, the UPP won thirteen seats, ${ }^{4}$ electing seven constituency National Assemblymen and six proportional party-list National Assemblymen. After this election, however, severe factional strife were ignited by a revelation that there had been election fraud in selecting party-list candidates. In September 2012, party members affiliated with the former Participation Party and the New Unified Solidarity for the Progressives defected from the UPP to found the Progressive Justice Party (now the Justice Party).

In the wake of political turmoil, only five National Assemblymen remained in the UPP who had been politically suspicious of "pro-North Korean" attitude. In September 2013, Lee Seok-ki, one of the remaining UPP National Assemblymen, was accused by the National Intelligence Service ("NIS") of plotting a violent rebellion in a couple of meetings led by the so-called "RO" (Revolution Organization), an allegedly pro-North Korean underground political group. In February 2014, Lee and his followers were convicted of plotting rebellion at a District Court, although several cases of manipulation of evidence by NIS were found and accusations were heavily based upon an informer within the allegedly rebellious group. In August 2014, however, they were found not guilty of the charge of rebellious conspiracy at the appellate instance, but were instead convicted of inciting rebellion and sentenced to nine years imprisonment. ${ }^{5}$

In November 2013, the Park Geun-hye government abruptly filed a dissolution case against the UPP in the CCK, despite the fact that the Supreme Court did not

3 This section was basically based upon Dissolution of the Unified Progressive Party, 2013 Hun-Da 1, Dec. 19, 2014, 26-2(Ha) KCCR 1 <available only in Korean>, available at http://search.ccourt.go.kr/ths/pr/ths_pr0101_P1.do (last visited on Apr. 22, 2017).

4 There are 300 seats in the National Assembly, which used to be composed of 54 proportional party-list seats and 246 constituency seats. These numbers were changed respectively to 47 and 253 following the 20th general election in 2016.

5 Supra note 3. 
settle Lee's rebellion case. President Park, the then head of the government, did not take part in any official deliberation. Although Article 89 of the Constitution of the Republic of Korea ("ROK") requires the State Council, the chairperson of which is the president, to deliberate the initiation of a case for dissolution of a political party. The Justice Minister representing the government accused the UPP of violating the democratic basic order on several counts, the main thrust of which can be narrowed down to two allegations. First, the main objectives of the UPP are identified in its programs such as 'progressive democracy' which is based upon the sovereign and self-governing polity of peoples consisting of laborers, farmers, and businessmen of small and medium-sized corporations who were not compatible with the democratic basic order. Second, activities of party members imputable to the party as a whole (e.g., Lee's rebellion case) were contrary to the democratic basic order. In addition, the government sought for every UPP National Assemblyman to be deprived of his membership of the National Assembly, even though no positive law justified it. ${ }^{6}$

On December 19, 2014, the majority (eight justices) of CCK including its president Park Han Chul upheld the government's petition to disband the UPP, while Justice Kim Yi Su wrote a sole dissenting opinion. The timing of the dissolution decision was criticized not only by the UPP, but also the general public not only because the final decision of the Supreme Court on Lee's rebellion case was still pending at that time, but also because oral arguments and the deliberation of CCK seemed to be scarce to look at all the allegations raised by the government. In fact, unlike the CCK's conviction on the risk to the democracy which was committed by some leaders of the UPP, a month after the CCK's decision, the Supreme Court finally confirmed the appellate court's finding that Lee had 'incited' rather than 'plotted' pro-North Korean rebellion. ${ }^{7}$

\section{B. The Juristic Grounds}

The CCK stressed that the military confrontation between the two Koreas should have been considered seriously, while applying legal principles and rules governing

\footnotetext{
Id.

See Supreme Court Decision 2014Do310978(en banc), Jan. 22, 2015 <available only in Korean>, available at http:// glaw.scourt.go.kr/wsjo/panre/sjo 100.do?contId=2172144\&q=\%ED $\% 86 \% \mathrm{~B} 5 \% \mathrm{ED} \% 95 \% \mathrm{~A} \% \mathrm{EC} \% \mathrm{~A} 7 \% 84 \% \mathrm{~EB} \% \mathrm{~B}$ $3 \% \mathrm{~B} 4 \% \mathrm{~EB} \% 8 \mathrm{~B} \% \mathrm{~B} 9 \& \mathrm{nq}=\& \mathrm{w}=$ total $\&$ section $=\&$ subw $=\&$ subsection $=\&$ subId $=2 \& \mathrm{csq}=\&$ groups $=\&$ category $=\&$ outm $\mathrm{ax}=1 \& \mathrm{msort}=\&$ onlycount $=\& \mathrm{sp}=\& \mathrm{~d} 1=\& \mathrm{~d} 2=\& \mathrm{~d} 3=\& \mathrm{~d} 4=\& \mathrm{~d} 5=\& \mathrm{pg}=0 \& \mathrm{p} 1=\& \mathrm{p} 2=\& \mathrm{p} 3=\& \mathrm{p} 4=\& \mathrm{p} 5=0 \& \mathrm{p} 6=\& \mathrm{p} 7=\& \mathrm{p} 8=$ $0 \& \mathrm{p} 9=\& \mathrm{p} 10=\& \mathrm{p} 11=\& \mathrm{p} 12=\& \mathrm{sysCd}=\& \mathrm{tabGbnCd}=\& \mathrm{saNo}=\& \mathrm{joNo}=\&$ lawNm $=\&$ hanjaYn $=\mathrm{N} \&$ userSrchHistNo $=\&$ popt ion $=\&$ srch $=\&$ range $=\&$ daewbyn $=\mathrm{N} \&$ smpryn $=\mathrm{N} \&$ tabId $=($ last visited on Apr. 22, 2017) .
} 
the dissolution of political parties to the UPP case. ${ }^{8}$ The majority opinion in this case (hereinafter the majority) assumed that universal norms developed at the international level could be moderated to consider the harsh political reality of South-North military division. Hence, not only the procedural standards (evidence of facts concerned), but also the substantive criteria (the merits of the case) could be proved and evaluated. ${ }^{9}$

In the introduction of the opinion, even the majority did not hesitate to confirm the importance of a pluralist party system and the necessity of strict norms to govern the exceptional measure like the dissolution of political parties. ${ }^{10}$ The majority recognized that dissolution of a political party had to be the last resort initiated in an exceptional situation, where no other moderate means were available to protect the democratic basic order. It was also accepted that as the only substantive constitutional element in deciding whether the party concerned should be disbanded, the democratic basic order had to be constructed as strictly as possible to the 'minimal' extent of its literal meaning that "without the protection of such order, a constitutional democratic system cannot be maintained." 11 It confined the content and scope of this order to only the 'political' order, ${ }^{12}$ by which it meant, in principle,

\footnotetext{
A political order, being established in the pluralist world view, by cherishing the pluralist world view, cherishing self-controlled reason of individuals, and assuming relative truthfulness and rationality of every political opinion, is to be constituted and operated under the principles of liberty, equality, and democratic decisionmaking, so that the rule of the majority caring for the minority and the negation of all the violent, arbitrary dominations are esteemed. ${ }^{13}$
}

It is said that specific examples of such basic order include the sovereignty of the nation, the protection of basic human rights, the separation of powers, the pluralist party system, etc. In this narrow construction of the democratic basic order, political criticism of the socio-economic system, e.g., capitalism, or even praise of communism and socialism itself cannot be regarded as being contrary to such an order. Furthermore, the majority made it clear that the violation of the democratic basic order could not be constituted by a mere breach or conflict with such order. In

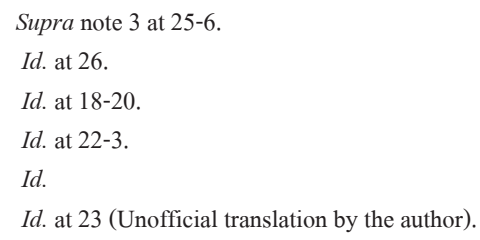


this case, however, the government is required to verify that objectives or activities of political parties bring about 'specific danger' (具體的 危險性) in which the “real or actual risk" (實質的 害惡) to the democratic basic order takes place. ${ }^{14}$ Finally, the majority moved on to opine, despite the government's argument, that the principle of proportionality or the prohibition of excessive restriction enshrined in Article 37(2) of the ROK Constitution must be complied with in this case. ${ }^{15}$

\section{The Court's Fndings}

The majority, applying procedural and substantive standards to the UPP case, held that both the objectives and activities of the UPP violated the democratic basic order. As far as its objectives were concerned, the majority found that the "progressive democracy' manifest in the UPP's program as its guiding idea had been introduced and consistently supported by the so-called 'independence faction'(自主派), the ideological origin of which can be traced back to the so-called 'National Liberation' (“NL”) (民族解放) line in the history of the progressive movement in Korea since the late 1980s. ${ }^{16}$ The assertive finding of the majority was that the independence faction or NL had consistently supported the people's democratic revolution to emancipate [South] Korean society from the American colonial domination and became the 'main forces' of the UPP by leading the party to the pro-North Korean activities such as the Federal Unification Plan and the withdrawal of the US Forces in Korea. ${ }^{17}$ It also found that 'progressive democracy' was a transitional ideology intended to serve as a bridge from free or liberal democracy to North Korean-style socialism. ${ }^{18}$ The majority also found a number of the National Security Act cases, in particular, from Lee's rebellious case mentioned above, that the 'main forces' of the UPP had a 'concealed intention' to overthrow the free or liberal democratic polity by moving in the direction of making a new constitution based upon progressive democracy. ${ }^{19}$

Insofar as anti-democratic activities were concerned, the majority found that those convicted in the case of Lee's rebellion were outright followers of the so-called “Juche (self-reliance) ideology”(主體思想) advocated by Kim Il Sung, the former North Korean dictator, and they were holding political meetings in which they jointly plotted to carry out vehement measures such as the deconstruction of national

\footnotetext{
Id. at 24 .

5 Id. at 24-5.

16 Id. at $101-2$.

17 Id. at $54-83$.

18 Id. at $75-82$.

19 Id. at 83-98.
} 
infrastructure facilities and the manufacture or depredation of arms or weapons in case of war between the two Koreas. ${ }^{20}$ Finally, the majority concluded that, as a whole, those seditious activities could be imputed to the party on the ground that Lee had been a leader of the key group of the 'independence faction' and the UPP altogether and their key leaders and followers sided with Lee since the case was first revealed. $^{21}$

Having abruptly made these findings, the majority held that objectives of those pursuing progressive democracy could be regarded as supporting the socialist regime in the North. The majority also held that rebellious activities of the main forces of the UPP led to the negation of the rule of law, democratic decision-making, and the existence of the state in terms of their contents while, in terms of method or characteristic, were incompatible with the democratic idea by using violence or deception as political means to accomplish their own opinions. ${ }^{22}$ In addition, the majority considered that such activities go beyond the constitutional limit on the freedom of expression and represent the 'specific danger' of inflicting "real or actual risk" to the democratic basic order. ${ }^{23}$ Lastly, it was held that the dissolution of the UPP was compatible with the principle of proportionality. ${ }^{24}$ Stressing the 'preventive' characteristic of such a measure, the majority opined that dissolution of the UPP could be justified by the UPP's objectives and activities concerned which had a characteristic of such 'grave unconstitutionality.' As a result, it could not be compensated by alternatives to the dissolution of the party itself. ${ }^{25}$ The majority turned down the argument that since the dissolution of political parties must be an extreme and exceptional resort, such a measure must be used with the utmost restraint as long as the public political forum functions well. ${ }^{26}$ Reminding that the Nazi Party took power in only four years between 1928 and 1932, the majority looked down on those supporting cautious approach as having a 'too optimistic' appraisal of the UPP's prospects. ${ }^{27}$ Striking a balance between interests or 'social needs,' the majority opined that such public values worked as the protection of the democratic basic order, the plurality and relativism of the democratic political order overwhelmingly outweighed the severe limitation on political freedom of the people

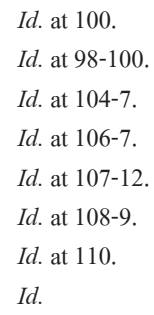


or the party concerned. ${ }^{28}$

Generally speaking, the majority, based upon the political reality of military confrontation with North Korea, took a very lenient stance in the application of principles and rules governing the dissolution of political parties. In addition, the majority did not stop to disband the UPP and went further to deprive the five lawmakers of their memberships from the National Assembly, even though there is no positive law at all for such deprivation. The majority considered that the effectiveness of the dissolution decision could not be guaranteed if representative members were allowed to keep their status as lawmakers because they could pursue the same objectives as the disbanded UPP in the political arena. ${ }^{29}$ Based on the situation of emergency, the majority assumed that even the people's choice of their representatives could give way to the necessity of militant democracy, and the lack of a statutory basis could not override such an extraordinary necessity. ${ }^{30}$

\section{The Criticism}

\section{A. Distorted Principles}

The seemingly stringent standards of the majority hid some inherent loopholes contrary to the nature of the dissolution of political parties, i.e., the last and exceptional resort to be used with restraint under strict judicial supervision. In fact, the majority dared to look down on those supporting the severest approach as 'too optimistic. $^{31}$

The majority outlined the constitutional premises and crucial legal principles were required in this drastic infringement on a fundamental right to freedom of political expression and association. Such a radical measure leading to the enforced exclusion of political parties from the political process is based on the premise that even the most liberal and mature pluralist democracy may put the political system in danger. It induced mob rule in case an exceptional judicial safeguard may intervene

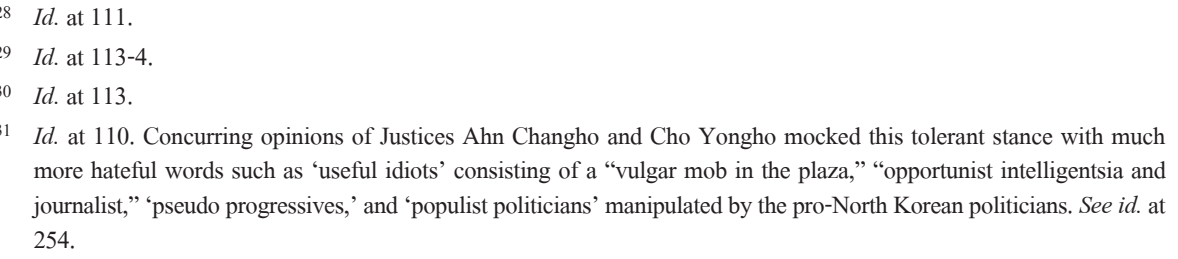
more hateful words such as 'useful idiots' consisting of a "vulgar mob in the plaza," "opportunist intelligentsia and journalist," 'pseudo progressives,' and 'populist politicians' manipulated by the pro-North Korean politicians. See id. at 254 . 
appropriately in the political process. ${ }^{32}$

The majority was quite biased by the military confrontation between the two Koreas, overlooking the harsh nature of the legal regime envisaged to regulate political expression and participation. ${ }^{33}$ As revealed even in the case of Lee's rebellion, the National Security Act prohibits any activities to praise North Korea, or inspire and incite people to follow its policies. ${ }^{34}$ A number of regulations are rampant in election law, the law of political parties and political finance curb general political expression and activities. ${ }^{35}$ Forming or partaking in a political party may require notable severe sacrifices of individuals as they have to endure surveillance by law enforcement, social bias, and even the threat to normal economic life. Putting national legal regime aside, private regulation in the form of the code of conduct used in private-sector personnel policy hinders ordinary people from being interested in political parties. In fact, under the legal regime and social atmosphere pertaining to the deep 'Red complex,' any overt pro-North Korean movement would be unthinkable.

From this point of view, the majority seriously excluded an important element in the principle of proportionality. Since its landmark decision in the United Communist Party of Turkey and others $v$. Turkey, ${ }^{36}$ the ECtHR established the basic jurisprudence

32 Following a consultative report (CDL-INF (98) 14) on the prohibition of political parties in 1998 based upon questionnaires joined by 40 countries, the Venice Commission adopted the guidelines on prohibition and dissolution of political parties and analogous measures. See Venice Commission, Guidelines on Prohibition and Dissolution of Political Parties and Analogous Measures, CDL-INF (Jan. 10, 2000) at 1, available at http://www.venice.coe.int/ webforms/documents/default.aspx?pdffile=CDL-INF(2000)001-e (last visited on Apr. 22, 2017). Its first guideline states: "States should recognize that everyone has the right to associate freely in political parties. This right shall include freedom to hold political opinions and to receive and impart information without interference by a public authority, regardless of frontiers. The requirement to register political parties will not in itself be considered to be in violation of this right." See id. at 4. This guideline clearly stressed that only the pluralist political order enshrined in the protection of freedom of political association, including political party, can justify the necessity to regulate political parties because in a polity without safeguards of political association, the ban of a political party is not difficult so that any mechanism of dissolution of a political party may be of no practical use.

33 This stance is also different from the Guidelines of the Venice Commission stressing the importance of the right to a political party even in the time of public emergencies. The second guideline makes it clear that: "Any limitations to the exercise of the above-mentioned fundamental human rights through the activity of political parties shall be consistent with the relevant provisions of the European Convention for the Protection of Human Rights and other international treaties, in normal times as well as in cases of public emergencies." See id. at 4 . This reflects the experienced wisdom that authoritarian regimes tended to manipulate or even create public emergencies to oppress political oppositions. If public emergencies may be used to justify the negation of the pluralist order, no means would remain to resist authoritarian regimes. See generally A. Sázo, The Self-protecting Constitutional State, 12 E. Eur. Const. Rev. 78 (2003).

34 National Security Act, art. 7(1).

35 Jongcheol Kim, On Unconstitutional Elements of the Political Parties Act in South Korea [정당법상 위헌요소에 관한 소고: 정당의 헌법상 지위를 중심으로]<available only in Korean>, 7 ELECTION STUD. 35-57 (2016).

36 The United Communist Party of Turkey and others v. Turkey, Eur. Ct. H.R. (1998) (App. No. 133/1996/752/951) 
concerning the dissolution of political parties. The Court held that the interference with the applicants' rights to freedom of association must be justified against three criteria, ${ }^{37}$ among which the most crucial standard was the 'necessity' principle in which the interference with the exercise of the rights of the ECHR has to be assessed by the yardstick of what was "necessary in a democratic society." effort to uplift this standard by paying profound attention to the importance of freedom of association coupled with freedom of expression as a foundation of a democratic society, the ECtHR finally declared that the exceptions set out in Article 11 of the ECHR were to be construed 'strictly,' in particular where political parties were concerned so that "only convincing and compelling reasons could justify restrictions on such parties' freedom of association." 39 Furthermore, the Court made it clear that only a limited margin of appreciation on the part of the member States could be allowed in this field. ${ }^{40}$ It ruled out the applicability of the reasonable test in dissolution cases, but instead adopted the principle of proportionality in order to scrutinize whether the dissolution was "proportionate to the legitimate aim pursued" and whether the reasons adduced by the national authorities to justify it were "relevant and sufficient."

In subsequent cases, including Refah Partisi (The Welfare Party) and Others $v$. Turkey, ${ }^{42}$ the ECtHR elaborated the required "necessity of interference" in terms of a "pressing social need," which can be examined through three specific tests: first, whether there was plausible evidence that any risk to democracy was sufficiently imminent; second, whether the acts and statements of the party's leaders and members were imputable to the party as a whole; and, third, whether acts and

available at http://hudoc.echr.coe.int/eng?i=001-58128 (last visited on Apr. 22, 2017).

37 The other two criteria that could be easily satisfied in most regulations for their formal or nominal characteristics are as follows: first, it should be "prescribed by law," and, second, the relevant state should verify that the interference pursued legitimate aims like the protection of national security or public safety, the rights and freedoms of others, and health or morals. See id. $\uparrow$ 个 38-41.

38 Id.

39 Id. 9 ๆ $42-46$.

$40 \quad$ Id. $₫ 46$.

41 Id. 47. This is in line with the Guidelines of the Venice Commission on this issue: "Legal measures directed to the prohibition or legally enforced dissolution of political parties shall be a consequence of a judicial finding of unconstitutionality and shall be deemed to be an exceptional nature and governed by the principle of proportionality." See supra note 28 at 5. This is also reconfirmed by the Code of Good Practice in the Field of Political Parties adopted by the Venice Commission at its 77th Plenary Session (Dec. 12-13, 2008), CDL-AD(2009)021, available at http:// www.venice.coe.int/webforms/documents/?pdf=CDL-AD(2009)021-e (last visited on Apr. 22, 2017).

42 Refah Partisi (The Welfare Party) and Others v. Turkey [GC], 2003-II Eur. Ct. H.R. 11 (Nos. 41340/98; 41342/ 98;41343/98; 41344/98,), available at http://www.echr.coe.int/Documents/Reports_Recueil_2003-II.pdf (last visited on Apr. 22, 2017). 
statements imputable to the party formed as a whole that gave a clear picture of a model of society by the party that was incompatible with a "democratic society. ${ }^{43}$ Regarding the first specific test, the ECtHR delivered two important rules related to the verificatn of evidence. First, it declared that not only the constitution and program of a political party, but also concealed objectives and intentions resulting from the comparison of the program and the actions of the party's leaders and the positions they defended needed to be taken into account. ${ }^{44}$ Second, it also considered that a power of preventive intervention on the government could be recognized so that it could not require any specific undertaking to implement a policy, even though the danger of the policy for democracy was sufficiently established and imminent. ${ }^{45}$

Notwithstanding the elaborate jurisprudence on the principle of proportionality in the field of dissolution of political parties established by the ECtHR, CCK deliberately requires 'social need' rather than "pressing social need" in dealing with the UPP case. ${ }^{46}$ Suggesting the element of 'specific danger' inflicting "real or actual risk" to democracy in evaluating the social necessity, CCK deliberately omitted the 'sufficient imminence' that the ECtHR requires in this regard. ${ }^{47}$ If it seriously considered these elements as expected to play an important role in assessing evidence and political effects of dissolution of political parties, there would be no other way to take a much more strict approach than it actually did.

\section{B. Ignored Rule of Evidence and Wrong Application of Principles}

The reasoning of the majority in applying them to the facts was too abrupt and unconvincing to persuade the party concerned. It seemed to fail to comply with the rule of evidence required for such a drastic conclusion. ${ }^{48}$

As Justice Kim Yi Su pointed out in his dissenting opinion, evidence on objectives and activities of a political party accused of violating the democratic basic

\footnotetext{
Id. $\uparrow 104$.

Id. ๆ 102.

Id.

46 Supra note 3, at 111.

47 Id. See also supra note 36, $\uparrow 102$. This element of 'sufficient imminence' should be used in a strict manner. For details on the suggestion, see P. Macklem, Militant Democracy, Legal Pluralism and the Paradox of Self-Determination, 4 INT'L J. CONST. L. 514 (2006).

48 Considerable criticisms were raised to the decision of CCK in the UPP case that the rule of evidence was basically according to the rules of civil proceedings which by nature pertains to the lenient rule of evidence compared to the criminal or administrative proceedings. See, e.g., Tae-ho Chung, Some Problems with the Use of Civil Proceedings Law in the Procedure of Dissolution of Political Parties [정당해산심판절차에 대한 민사소송법령 준용과 한계], 49(4) KyUnGHeE L. Rev. 121-59 (2014). < available only in Korean>
} 
order should satisfy the austere probative standards, particularly concerning the relationship between individual members and the party as a whole. ${ }^{49}$ Furthermore, since almost all objectives and activities were conducted verbally, they should be assessed by objective and universally established rules of interpretation as much as possible. There is doubt that the majority complies with this rule. In the majority's reasoning, some essential definitions and categorizations are crucial to identifying the imputability of the party as a whole and the responsibilities of the actors missing or too vague to accomplish this end. E.g., the majority did not attempt to define not only who were composed of the 'main forces' of the UPP, but also whether the other political groups within and outside UPP had any causational relationship between them. What they did is only mentioning the names of some groups, of which key members had involved organizational control of the UPP and other extra-party seditious activities. The majority presupposed, rather than verified, the 'concealed' intention of factions and groups concerned with pursuing violent revolution in the name of 'progressive democracy' in resisting the authoritarian regimes in the 1980s. They did not clearly and convincingly reveal the relationship between them, either. ${ }^{50}$ Furthermore, the equation of 'progressive democracy' with the North Korean-style socialist regime is "nonsense on stilts," though it can be viewed as a socialist system or idea in the broadest sense. ${ }^{51}$ If accepting that the only criterion for the violation of the democratic basic order is whether political opinion or activities support the existence of North Korea and its main policies, it would result in an ironical proposition that North Korea could enjoy the trumping power to intervene in the constitutional politics of South Korea. Constitutional matters have to be assessed by whether they are compatible with constitutional principles and values rather than what positions the North Korean regime takes. The superficial concurrence of political opinions and ideas between the anti-government activist groups of South Korea and the North Korean regime may be quite a natural phenomenon as a way of opposing arguably authoritarian regimes.

Another point of criticism may be the way in which the majority tried to strike the balance between the public interests expected from the dissolution of the UPP and the constitutional rights and institutions damaged by this harsh measure.

49 Supra note 3, at $203 \&$ 237-9. This element is very important in striking a balance between individual and collective responsibility that is crucial in the dissolution of an association like a political party. The Venice Commission provides a manifest guideline as follows: "A political party as a whole cannot be held responsible for the individual behavior of its members not authorized by the party within the framework of political/public and party activities." See supra note 32 , at 5 .

50 These arguments were persuasively delivered by Justice Kim Yi-Su. See supra note 3, at 186-203 \& 240.

51 Id. at 151-86. 
The majority regarded "the protection of the democratic basic order including the principle of popular sovereignty, the safeguards of basic rights, the pluralist political party system, the separation of powers" and "the guarantee of diversity and relativism of democracy" as the public interests in this case. 52 However, these interests are too broad to be balanced. They can be fulfilled not only by the dissolution of the UPP, but also by the protection of the liberties of political association and activities of the UPP. Therefore, the interests taken on board in this balancing act must be given concrete details, e.g., the marginal interests of the extreme preventive measure instead of alternative sanctions targeting individual wrongdoing in criminal or administrative proceedings. It seems that this failure of the majority in deploying the specific interests to the dissolution of the UPP in great details is too serious to justify its conclusion.

In addition, the reasoning of the majority in applying the principle of proportionality and social needs is quite contrary to the historical context and political arrangements in Korea. Since 1948, as the harsh legal regime has been limiting the freedom of political expression and activities which has resulted in apolitical or anti-political sentiments - particularly what may be called the 'red complex' endemic in the Korean society - no left-wing or progressive party has obtained enough seats to become a negotiating group within the legislature. ${ }^{53}$ The significant progress of any left-wing, particularly pro-North Korean, would be unthinkable in the foreseeable future.

In sum, as the dissenting opinion persuasively put forward, the majority's application of the principle of proportionality failed to prove that, despite the aberrant activities of some members, the UPP as a whole undertook 'specific danger' leading to "real or actual risk" to the democratic basic order.

\section{Judicial Activist Outreach Giving Way to Political Oppression}

In the UPP case, the majority tried to defend themselves hoping that the dissolution of the UPP would make the political process more open and diverse in terms of the ability of the political spectrum. They maintained, on the one hand, to protect constitutional progressive movements in their quest for social democracy and, on the other, to obtain political stability, which has been threatened by seditious activities

52 Id. at 111.

53 Article 33(1) of the National Assembly Act requires the minimum 20 out of 300 seats for a political group to be recognized as a negotiation group with the legislature. Neither Korean political parties have overtly declared comprehensive "pro-North Korean" policies in elections since 1948, nor parties that have been suspected of pro-North Korean tendencies including the UPP have gained the status of negotiation group in the National Assembly. 
of pro-North Korea forces. ${ }^{54}$ However, the lenient standard CCK deployed and applied in a distorted manner in the UPP case may pave the way for ideologically driven law enforcement agencies to shift their burden of proof to the suspects whenever the opinions or activities have something to do with pro-North Korea in constitutional cases. In other words, while assessing the constitutionality of political opinion, not only politicians, but also ordinary citizens are subject to a kind of censorship whenever they form and communicate any opinion in relation to North Korean issues. This means not the state but citizens must obligate themselves to prove prospectively or retrospectively their non-alliance with North Korea against fundamental freedoms of conscience and expression.

Further, the extreme judicial activism deployed by the majority in the UPP case was evidenced by its additional decision to disqualify five members of the National Assembly affiliated with the UPP. CCK addressed it without any positive legal ground and independent examination of individual members on their involvement with the dissolved party's violation of the democratic basic order. ${ }^{55}$ According to the majority, disqualification could make the dissolution of a political party (UPP) effective and useful. Such extreme action would be protecting the constitution or the ideal and principles of militant democracy. It is the only rationale that CCK provided in this case. ${ }^{56}$ This stance, however, can be criticized on at least two grounds. First, it can be incompatible with the rule of law requiring a statutory basis for the restriction of civil liberties. Second, it can contradict to the principle of representative democracy giving a preferred position to the constitutional status of the representative of the people as opposed to the status of the representative of a political party. ${ }^{57}$

Constitutional adjudication including the dissolution of political parties can be theoretically justified in its role as a check and balance to the political and executive oppression of human rights and encroachment on democracy. Paying too much reverence to political power in cases that have an immense social influence may easily undermine the institutional integrity of constitutional adjudication. In particular, if such a political case is decided without plausible evidence under universally recognized principles and rules, it can expose the worst effect of the

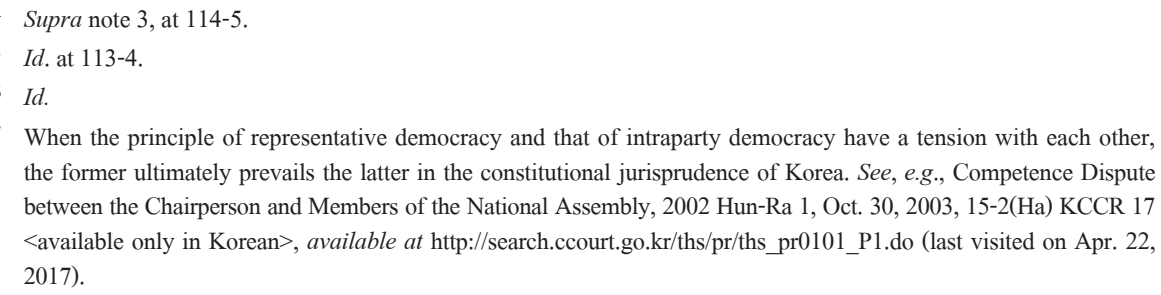
the former ultimately prevails the latter in the constitutional jurisprudence of Korea. See, e.g., Competence Dispute between the Chairperson and Members of the National Assembly, 2002 Hun-Ra 1, Oct. 30, 2003, 15-2(Ha) KCCR 17 <available only in Korean>, available at http://search.ccourt.go.kr/ths/pr/ths_pr0101_P1.do (last visited on Apr. 22, 2017). 
"judicialization of politics."

\section{Conclusion}

In the UPP dissolution case, as the majority of CCK delivered unconvincing reasoning and far too lenient review of constitutionality, it lost institutional trust. Their jurisprudence will be very dangerous and unreasonable. CCK turned the democratic republic into an emergency state by denying universal norms in this area and pursuing biased political reality and perspectives. It was assumed that, as far as the issue of North Korea was concerned, the constitutional principle of "in dubio pro libertate" could be discarded. In this case, CCK recognized that the representative democracy based upon popular sovereignty could be overridden without any positive legal ground just when any political opinions and activities of the National Assemblymen were suspicious to be pro-North Korea or they do not blame North Korea at the same or similar level with that of right wing political group. Also, if a politically violent tendency of individual members of a political party could be recognized (not in specific actions but in expressions), the party as a whole could be dissolved even without plausible evidence that such concealed intention could cause 'sufficiently imminent' risk to the democratic order. Is this jurisprudence compatible with the ideal of the democratic republic the ROK Constitution enshrines? Would it be fundamentally differentiated from the North Korean authoritarian regime?

It is probing that the majority is driven to the harsh but unconvincing conclusion in the UPP case. The majority opinion could have taken other options that could suffice not only for its credential, but also for the prospective development of truedemocracy in Korea. Based upon the problems with the majority reasoning, at least two scenarios deserve to be mentioned. First, CCK could have delayed the final decision until it looked thoroughly into all the meaningful evidence, at least, until the Supreme Court released the final ruling on the case of so-called Lee's rebellion. By this stance, they could avoid some of the political conspiracy haunting them after the dissolution of the UPP and subsequently, their credential as the bastion of human rights and democracy could be maintained. Second, the majority could take the basic frameworks of dissenting opinion, through changing the governing jurisprudence to be more in line with European norms. By this option, they could have authentically

58 For an ambivalent nature of this phenomenon, see Jongcheol Kim \& Jonghyun Park, Causes and Conditions for Sustainable Judicialization of Politics in Korea, in The Judicialization of Politics In Asia, ch.3 (B. Dressel ed., 2012). 
provided the nation with the firm constitutional principle and its accompanying condition. In other words, the CCK could have made it clear that the enemies of democracy could be deprived of their political freedoms only on the condition that the government verifies the convincing evidence that their objectives and activities violate the democratic basic order and all the possible political and legal mechanisms are exhausted to avoid such a drastic measure.

It is regrettable that the CCK missed a good chance to shape a self-image of audacious umpire of constitutional conflicts, while rendering the nation itself by having the power to decide the destiny of the polity itself and any political association. 
